\title{
Early results of a trimodality treatment for superior sulcus tumors
}

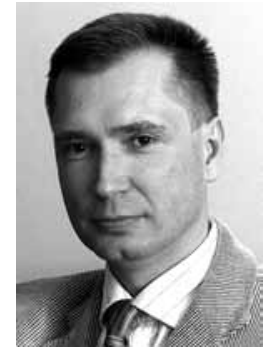

${ }^{1}$ Department of Thoracic Surgery, Medical University of Gdansk, Poland

${ }^{2}$ Department of Oncology and Radiotherapy, Medical University of Gdansk, Poland

${ }^{3}$ Chair and Clinic of Anesthesiology and Intensive Care, Medical University of Gdansk, Poland

Kardiochirurgia i Torakochirurgia Polska 2014; 11 (3): 268-272

\begin{abstract}
Introduction: Superior sulcus tumors are a unique form of lung cancer. Preoperative concurrent radio- and chemotherapy improves the results of treating these lung tumors.

Aim: The study aimed to assess the early results of a trimodality treatment for superior sulcus tumors.

Material and methods: Fifty-six superior sulcus tumors patients were operated on between 2006 and 2013. Data from 25 patients undergoing preoperative chemoradiotherapy were analyzed. Fifteen men and 10 women were treated (mean age: 59 years). All patients experienced pain in the pectoral girdle of the chest.

Results: Nineteen patients received preoperative chemoradiotherapy consisting of 2 chemotherapy cycles with cisplatin (a different number of cycles was administered in 6 cases) and irradiation at a mean dose of $51.2 \mathrm{~Gy}$ (30-60 Gy) in 25 fractions (25-30 fractions). All patients underwent upper lobectomy. Twenty-two patients underwent chest wall resection, whereas 3 patients underwent extrapleural excision of the infiltrate without rib resection. Stages IIB and IIIB were diagnosed in 15 and 10 patients, respectively. In 9 samples, no neoplastic features were found, 9 showed individual neoplastic lesions, and in 7 most tumor cells were necrotized. The R1 resection was noted in 2 patients. Mean hospitalization time was 13 days. No perioperative deaths were noted.

Conclusions: The trimodality treatment for superior sulcus tumors is a safe method. Perioperative mortality and the number of complications observed among patients treated with this method are similar to those observed in one-phase surgery. In over half of the patients, chemoradiotherapy resulted in complete or nearly complete remission of the neoplasm.

Key words: lung cancer, superior sulcus tumor.
\end{abstract}

\section{Streszczenie}

Wstęp: Rak szczytu płuca jest szczególną postacią raka płuca. Przedoperacyjna, równoczesna radio- i chemioterapia poprawia wyniki leczenia guza płuca w tej lokalizacji.

Cel pracy: Ocena wczesnych wyników skojarzonego leczenia raka szczytu płuca.

Materiat i metody: W latach 2006-2013 operowano 56 chorych z rakiem szczytu płuca. Przeanalizowano dane 25 chorych poddanych przedoperacyjnej radiochemioterapii. Leczono 15 mężczyzn i 10 kobiet w średnim wieku 59 lat. U wszystkich chorych występowały bóle w klatce piersiowej lub obręczy barkowej.

Wyniki: Dziewiętnastu chorych otrzymało przedoperacyjną radiochemioterapię $w$ formie 2 cykli chemioterapii $z$ cisplatyną (w 6 przypadkach podano inną liczbę cykli) oraz napromienienia w średniej dawce 51,2 Gy (30-60 Gy) w 25 frakcjach (2530 frakcji). U wszystkich chorych wykonano wycięcie górnego płata płuca. U 22 pacjentów wycięto ścianę klatki piersiowej, a u 3 zewnątrzopłucnowo naciek bez resekcji żeber. Stopień zaawansowania IIB i IIIB stwierdzono odpowiednio u 15 i 10 chorych. W 9 preparatach nie stwierdzono cech nowotworu, w 9 występowały pojedyncze wyspy nowotworowe, a w 7 zaobserwowano martwicę obejmującą większość komórek guza. Cechę R1 stwierdzono u 2 chorych. Średni czas hospitalizacji wynosił 13 dni. Nie stwierdzono zgonów okołooperacyjnych.

Wnioski: Skojarzone leczenie guza szczytu płuca jest bezpieczną metodą. Okołooperacyjna śmiertelność i liczba powikłań wśród chorych leczonych skojarzoną metodą nie różnią się od liczby powikłań w jednofazowym leczeniu chirurgicznym. $U$ ponad połowy chorych pod wpływem radio- i chemioterapii uzyskuje się całkowitą lub prawie całkowitą remisję patologiczną nowotworu.

Słowa kluczowe: rak płuca, guz szczytu płuca (Pancoasta). 


\section{Introduction}

Superior sulcus tumors (SST) are a unique form of lung cancer, which is the largest source of cancer related mortality in the world [1-3]; they are located in the superior thoracic sulcus, infiltrating the chest wall and neighboring structures. It is a rare form of lung cancer, constituting 2-5\% of all lung cancers [7]. Preoperative concurrent radio- and chemotherapy improves the results of treating malignant tumors at this location in comparison with surgical treatment alone [4-6]. In the early stages of lung cancer, the treatment of choice is radical resection. However, in this particular case, in which the neoplastic infiltrate involves important anatomical structures, such as the stellate ganglion, brachial plexus, vertebral column, large vessels, or esophagus, unaided surgical treatment is difficult and burdened with complications; moreover, it involves the possibility that complete oncological radicality, the primary prognostic factor for long-term survival, will not be achieved. Until the 1950s, superior sulcus tumors were considered inoperable, and radiotherapy was the treatment of choice [9]. Subsequently, the treatment of choice for SST was radiation therapy preceding a surgical procedure [12, 13]. Based on a report by Rush et al. [4], combination therapy consisting of concurrent preoperative radio- and chemotherapy with subsequent surgical treatment has been used on a larger scale since 2006.

In Gdańsk as well, SST were treated with this method since 2006. During the first 5 years, our center administered combined therapy for SST in 11 cases; a further 14 cases have been treated using this therapy during the last 2 years. This required the development of a strategy for managing patients in whom lung cancer was diagnosed in this location, in order to promptly diagnose and stage the disease and implement concurrent radiochemotherapy with subsequent surgical treatment within 4-6 weeks of the end of oncological treatment. This study presents the perioperative results of patients treated with concurrent preoperative radio- and chemotherapy and subsequent surgical treatment.

\section{Aim}

The aim of the study was to present the early results of a trimodality treatment strategy for superior sulcus tumors patients.

\section{Material and methods}

In the period 2006-2013, 56 superior sulcus tumor (SST) patients underwent surgical treatment at our institution. In total, 34 patients (60.7\%) received neoadjuvant therapy, including the following: radiation therapy (2 patients, $3.57 \%$ ), chemotherapy (7 patients, $12.5 \%$ ), and chemoradiotherapy (25 patients, $44.6 \%$ ). The study included patients presenting the radiological and clinical criteria of SST proposed by Detterbeck [5]. Data from patients were treated with radio- and chemotherapy with subsequent surgical treatment were analyzed retrospectively. The analysis included age, sex, type of surgery, operated side, clinical stage, histopathological diagnosis, smoking history, postoperative complications, completeness of the resection, and response to neoadjuvant therapy. Clinical staging was established by computed tomography of the chest, central nervous system (CNS), computed tomography, PET scans, endobronchial ultrasound (EBUS) examinations, and mediastinoscopy. Preoperative histopathological diagnosis was based on large-needle and fine-needle aspiration biopsy in 24 patients, and bronchofiberoscopy in 1 patient. All patients receiving the combination therapy were scored 0 or 1 on the WHO performance status scale. The assessment of respiratory fitness was based on a spirometric examination, a stair- climbing test, and a 6-minute walking test All the patients received chemoradiotherapy; 22 patients (88\%) received it as a concurrent treatment. The mean irradiation dose was 51.2 Gy (30-60 Gy) in 25 fractions (2530 fractions) (Table I). In 6 patients, the treatment regimens were different than those included in the table: 5 patients received 1 cycle of chemotherapy due to signs of intolerance, and 1 patient received 3 chemotherapy cycles. Perioperative mortality was defined as hospital mortality or death within 30 days after surgery. Poster lateral incision was the main surgical access. Anterior border of the resection specimen was divided using rib shears and than the ribs to be removed were disarticulated from the transverse process of the vertebral body and, the lung parenchyma was

Tab. I. Neoadjuvant therapy $(n=25,100 \%)$

\begin{tabular}{lcc}
\hline Cisplatin - etoposide & 21 & 84 \\
\hline Cisplatin - navelbine & 4 & 16 \\
\hline Radiation therapy (mean 51.2 Gy) & 25 & 100 \\
\hline Concurrent & 22 & 88 \\
\hline Sequential & 3 & 12 \\
\hline 2 cycles of chemotherapy & 19 & 76 \\
\hline Other number of cycles & 6 & 24 \\
\hline
\end{tabular}

Tab. II. Type of procedure, operated side, surgical access

\begin{tabular}{lcc} 
Upper lobectomy & $n$ & $\%$ \\
\hline Upper bilobectomy & 23 & 92 \\
\hline Right & 2 & 8 \\
\hline Left & 18 & 72 \\
\hline Posterolateral thoracotomy & 7 & 28 \\
\hline Sternotomy & 21 & 84 \\
\hline Anterior thoracotomy & 2 & 8 \\
\hline $\begin{array}{l}\text { Posterolateral thoracotomy with partial } \\
\text { sternotomy }\end{array}$ & 1 & 4 \\
\hline $\begin{array}{l}\text { Chest wall resection } \\
\text { Ribs (2-5) mean: } 3\end{array}$ & 22 & 4 \\
\hline No chest wall resection & 3 & 12 \\
\hline
\end{tabular}


excised en bloc with the chest wall. The types of surgical procedures are listed in Table II. In 1 patient, the posterolateral incision was supplemented with partial sternotomy in order to repair subclavian vessels. With regard to perioperative prophylaxis, the patients received: $2 \times 1.0 \mathrm{~g}$ of cefazolin ( 1 female patient received $2 \times 0.2 \mathrm{~g}$ of ciprofloxacin), $1 \times 0.04 \mathrm{~g}$ of omeprazole for the prevention of stress ulcers on the day of the procedure, and a prophylactic dose of low-molecular-weight heparin on the day before. The patients underwent early and intensive respiratory and physical therapy from postoperative day 0 . All patients were operated on under general anesthesia with one-lung ventilation using a double-lumen endotracheal tube.

\section{Results}

The patients operated on included 15 men (60\%) with a mean age of 57 years (42-72 years) and 10 women (40\%) with a mean age of 52.6 years (41-69 years). Seventeen patients $(68 \%)$ were smokers. The cTNM stage of over half of the patients was evaluated as IIB. In 9 cases (36\%), this assessment was based only on clinical evaluation, as the postoperative samples showed no neoplastic features. Squamous carcinoma was the most common neoplasm (Table III). All patients underwent lobectomy (Table II); in the case of 18 patients (72\%), it was performed on the right side. In 3 cases, the infiltration and subsequent resection pertained to the anterior part of the chest wall. In 5 patients, the chest wall defect was repaired with Prolene mesh. The remaining

Tab. III. Epidemiological data, cTNM stage, histopathological diagnosis

\begin{tabular}{lcc} 
Women & $n$ & $\%$ \\
\hline Men & 10 & 40 \\
\hline Age (years) & 15 & 60 \\
\hline Women & $41-69$ & mean: 52.6 \\
\hline Men & $42-72$ & mean: 57 \\
\hline Chest pain & 9 & 36 \\
\hline Shoulder pain & 7 & 28 \\
\hline Chest and shoulder pain & 8 & 32 \\
\hline Horner syndrome & 4 & 16 \\
\hline Smoking & 17 & 89.5 \\
\hline cTNM stage & 15 & \\
\hline II B & 10 & 60 \\
\hline III B & 16 & 40 \\
\hline Histopathological diagnosis & 5 & 64 \\
\hline Squamous carcinoma & & \\
\hline Adenocarcinoma & & \\
\hline Non-small-cell carcinoma & & \\
\hline
\end{tabular}

patients did not require reconstruction because of the defect's subscapular location. In 1 case, a resection of the Th1 vertebral body was performed with subsequent repair using a anterior plate and screw-rod system. Excision of the chest wall, involving 3 ribs on average (2-5 ribs), was conducted in 22 patients (88\%). In 3 cases (12\%), chest wall resection was not performed, as the tumor was removed extrafascially together with the soft tissues of the prevertebral region. In the postoperative samples of 9 patients (36\%), no neoplastic features were found; in 9 samples (36\%), individual neoplastic lesions were revealed, and in 7 (28\%) most tumor cells were necrotized (mean: $85 \%$, range: $70-95 \%)$. Neoplasms in R1 margins were found in 2 patients $(8 \%)$. The mean time of hospitalization was 13.5 days (6-30 days). No mortality was noted during the postoperative course. Postoperative complications occurred in 7 patients (28\%) (Table IV). The most common complications were supraventricular cardiac dysrhythmia and retention of secretion in the bronchial tree requiring repeated aspirations. Complications after neoadjuvant therapy occurred in 6 patients (24\%) (Table V). Nineteen patients (76\%) required the transfusion of 2-9 (mean: 3.5) units of packed red blood cells due to low parameters of blood morphology (hemoglobin below $9 \mathrm{~g} / \mathrm{dl}$ ).

\section{Discussion}

In 1838, Edwin Hare described the case of a patient with a pathological mass in the lung apex, shoulder pain, and athrophy of the hand muscles supplied by ulnar nerve [10]. Eighty-six years later, 7 patients with similar symptoms were described by the radiologist Henry Pancoast [11]. Until the 1950s, Pancoast cancer was considered inoperable,

Tab. IV. Postoperative complications $(n=7,28 \%)$

\begin{tabular}{lll} 
Complication type & $n$ & $\%$ \\
\hline Supraventricular cardiac dysrhythmia & 6 & 24 \\
\hline Numerous bronchofiberoscopic aspirations & 5 & 20 \\
\hline $\begin{array}{l}\text { Chronic air leak (<7 days) } \\
\text { expansion of the remaining lung) }\end{array}$ & 2 & 8 \\
\hline $\begin{array}{l}\text { Pneumonia } \\
\text { Repeat thoracotomy (hematoma) }\end{array}$ & 2 & 8 \\
\hline $\begin{array}{l}\text { Respiratory failure requiring mechanical } \\
\text { ventilation }\end{array}$ & 1 & 4 \\
\hline
\end{tabular}

Tab. V. Complications after neoadjuvant therapy $(n=6,12 \%)$

\begin{tabular}{lll} 
Complication type & $n$ & $\%$ \\
\hline Neutropenia & 3 & 12 \\
\hline Thrombocytopenia & 1 & 4 \\
\hline Bronchitis & 1 & 4 \\
\hline Acute kidney injury & 1 & 4 \\
\hline Esophagitis & 1 & 4 \\
\hline
\end{tabular}


and radiotherapy dosed at 45-70 Gy was the treatment of choice. The 5 -year survival rate was $5-10 \%$ at the time [9]. In 1953, Chardack and Mc Callum published the results of combination therapy for a Pancoast tumor in a patient who, after undergoing radiation therapy (dosed at 65 Gy) and subsequent anatomical resection, survived for 5 years without any disease symptoms [12]; in 1975, Paulson published the results of surgical treatment for Pancoast tumors conducted in 61 patients, who received radiation therapy dosed at $30 \mathrm{~Gy}$ in 10 fractions and underwent subsequent surgical treatment; 5-year survival was confirmed in 34\% of these patients [13]. Radiation therapy preceding surgical treatment became the standard procedure in the treatment of locally advanced lung cancer.

The $21^{\text {st }}$ century begun with the introduction of a tripartite treatment, i.e. surgical treatment preceded by chemoradiotherapy. In 2005, the most prominent prospective multicenter study by Rusch et al. demonstrated that using preoperative chemoradiotherapy facilitates a complete pathological response rate of $56 \%$ and 5 -year survival in $44 \%$ of treated patients. Perioperative mortality was $4 \%$, and $52.3 \%$ of patients suffered from postoperative complications, primarily atelectasis, and pneumonia [4]. Since the latter study was published, the three-phase treatment has become a recommended standard for this kind of tumors.

The use of preoperative chemoradiation is associated with an increase in the prevalence of postoperative complications and perioperative mortality compared to traditional lobectomy for lung cancer [17]. However, most of the early results of the few published reports of combination therapy for SST employing neoadjuvant chemoradiotherapy and subsequent surgery confirm the safety of this strategy. Perioperative mortality is relatively low, ranging between $0 \%$ and 6.9\%; complications occur in 10.3-45\% of patients and are primarily pneumonia, bronchitis, and atelectatic lesions requiring frequent bronchial aspirations $[8,16,18]$. The complete pathological response rate after neoadjuvant chemoradiotherapy ranges from $56 \%$ to $62 \%$, and oncological radicality is achieved in $81-100 \%$ of patients $[4,8,16,18]$.

In our study, postoperative complications occurred only in 7 patients (28\%). This probably stems from numerous factors, the most important among them being age, very detailed preoperative diagnostics, prolonged antibiotic prophylaxis, longer hospital stay aimed at avoiding delayed complications, and the experience of the attending medical team in this type of procedure.

Rusch et al. did not perform chest wall resection in $14.7 \%$ of the operated patients and provided no explanation for this [4]. Among the patients operated on in our center, chest wall resection was not performed in 3 cases (12\%), because the tumor was removed extrafascially. The first patient was 67 years old and suffered from cardiac comorbidities; he had survived two myocardial infarctions and had undergone coronary artery stenting. His upper lung lobe was excised extrapleurally; numerous intraoperative examinations did not reveal any signs of a neoplasm. Due to the high perioperative risk, extensive chest wall resection was avoided. In the second case, after neoadjuvant therapy, the infiltrate was "scratched away" from the ribs and mostly involved the mediastinum from the side of the thoracic inlet, which was excised en bloc with the right upper lobe. The histopathological samples of this patient also showed no signs of a neoplasm. In the third case, the infiltrate involved the mediastinum from the thoracic inlet to the azygos vein. A lobectomy was performed, and the infiltrated mediastinal fat was excised en bloc with the lymph nodes. Oncological radicality was achieved in 23 patients (92\%). In one patient, a repeat analysis of the samples yielded ambiguous results. In another patient, positive margins were diagnosed in the ad-vertebral (Th1 and Th2) line of rib excision, specifically on the pleura and the soft tissues of the spine that were excised (cT4). No perioperative deaths were noted. In 9 postoperative samples (36\%), no neoplasm was found after neoadjuvant therapy; this is similar to the reports by Rusch et al. [4] and Pourel et al. [14], in which this percentage was $56 \%$ and $62 \%$, respectively.

Some interesting results were reported by Ginsberg, who compared the survival of patients with N3 involvement of the ipsilateral supraclavicular lymph nodes and patients with N2 involvement. Among the patients with supraclavicular lymph node involvement, $15 \%$ survived for 5 years; there were no 5 -year survivals among the patients with N2 involvement [15]. These results may suggest that, in the case of Pancoast tumors, supraclavicular lymph node involvement on the side of the tumor should be classified as parameter N1 instead of N3.

The early results of the tripartite treatment for Pancoast tumors at our institution appear to be satisfactory. They correspond to the results of other publications on the same subject. It should be underscored once more that patients undergoing three-phase treatment require special postoperative care. Relieving postoperative pain, intensive respiratory and physical therapy, and employing prolonged prophylaxis or empirical antibiotic therapy in the presence of even a minimal increase of inflammatory parameters (CRP, WBC) are factors that play a fundamental role in avoiding postoperative complications. The mean length of hospital stay at the clinic was 13 days, which is twice the duration of hospitalization after traditional lobectomy. In the USA, the hospitalization time is shorter (7 days), which is related to differences in the management of postoperative care [4].

\section{Conclusions}

Trimodality treatment for superior sulcus tumors, consisting of concurrent chemotherapy and radiation therapy with subsequent surgical resection, is a safe method. Perioperative mortality rates and the number of complications among patients treated with the combined method do not differ from the numbers observed in one-phase surgery. In more than half of the patients, radio- and chemotherapy resulted in complete or nearly complete remission of the 
neoplasm. Assessment of the oncological efficiency of this treatment strategy requires further observation.

\section{Disclosure}

The authors report no conflict of interest. The study was supported by Fundacja "Torakochirurgia Gdańska”.

\section{References}

1. Jemal A, Bray F, Center MM, Ferlay J, Ward E, Forman D. Global cancer statistics. CA Cancer J Clin 2011; 61: 69-90.

2. Zatoński W. Nowotwory złośliwe w Polsce. Centrum Onkologii - Instytut im. M. Skłodowskiej-Curie, Warszawa 2009.

3. Wojciechowska U, Didkowska J, Zatoński W. Nowotwory złośliwe w Polsce w 2008 roku. Centrum Onkologii - Instytut im. M. Skłodowskiej-Curie, Warszawa 2010.

4. Rusch VW, Giroux DJ, Kraut MJ, Crowley J, Hazuka M, Winton T, Johnson DH, Shulman L, Shepherd F, Deschamps C, Livingston RB, Gandara D. Induction chemoradiation and surgical resection for superior sulcus nonsmall cell lung carcinomas: long-term results of Southwest Oncology Group Trial 9416 (Intergroup Trial 0160). J Clin Oncol 2007; 25: 313-318.

5. Detterbeck FC. Changes in the treatment of Pancoast tumor. Ann Thorac Surg 2003; 75: 1990-1997.

6. Albain KS, Swann RS, Rusch VW, Turrisi III AT, Shepherd F, Smith CJ, Gandara D, Johnson DH, Green MR, Miller RC. Intergroup NALC Phase III study of concurrent chemotherapy and radiotherapy (CT/RT) vs CT/RT followed by surgical resection for stage IIIA(pN2) non-small cell lung cancer (NSCLC): outcomes update of North American Intergroup 0139 (RTOG 9309). Proc Am Soc Clin Oncol 2005; 23: 624.

7. Albain KS, Rusch VW, Crowley J, Rice TW, Turrisi III AT, Weick JK, Lonchyna VA, Presant CA, McKenna RJ, Gandara DR, Fosmire H, Taylor SA, Stelzer KJ, Beasley KR, Livingston RB. Concurrent cisplatin/etoposide plus chest radio- therapy followed by surgery for stages IIIA (N2) and IIIBnon-small cell lung cancer: mature results of Southwest Oncology Groupphase II study 8805. J Clin Oncol 1995; 13: 1880-1892.

8. Kwong KF, Edelman MJ, Suntharalingam M, Cooper LB. High-dose radiotherapy in trimodality treatment of Pancoast tumors results In high pathologic complete response rates and excellent long-term survival. J Thorac Cardiovasc Surg 2005; 6: 1250-1257.

9. Safuh A. Pancoast's tumor: irradiation or surgery? Ann Thorac Surg 1979; 28: 578-586.

10. Hare ES. Tumour involving certain nerves. Lond Med Gaz 1838; 1: 16-18.

11. Pancoast HK. Importance of careful roentgen-ray investigations of apical chest tumours. JAMA 1924; 83: 1407-1411.

12. Chardack WM, MC Callum JD. Pancoast tumor: five-year survival without recurrence or metastases following radical resection and postoperative irradiation. J Thorac Surg 1956; 31: 532-534.

13. Paulson DL. Carcinomas in the superior pulmonary sulcus. J Thorac Cardiovasc Surg 1975; 70: 1095-1104.

14. Pourel N, Santelmo N, Naafa N, Serre A, Hilgers W, Mineur L, Molinary N, Reboul F. Concurrent cisplatin/etoposide plus 3D-conformal radiotherapy followed by surgery for stage IIB (superior sulcus T3NO)/III non-smallcell lung cancer yields a high rate of pathological complete response Eur J Cardiothoracic Surg 2008; 33: 829-836.

15. Ginsberg RJ, Martini N, Zaman M, Armstrong J, Bains M, Murt B, McCormack PM, Rusch VW, Harrison L. Influence of surgical resection and brachytherapy in the management of superior sulcus tumor. Ann Thorac Surg 1994; 57: 1440-1445.

16. Kappers I. Results of combined modality treatment in patients with nonsmall-cell lung cancer of the superior sulcus and the rationale for surgical resection. Eur J Cardiothorac Surg 2009; 36: 741-746.

17. Peedell C, Dunning J, Bapusamy A. Is there a standard of care for the radical management of non-small cell lung cancer involving the apical chest wall (Pancoast tumours)? Clin Oncol 2010; 22: 334-346.

18. Vos CG, Hartemink KJ, Blaauwgeers JLG, Oosterhuis JWA, Senan S, Smit EF, Thunnissen E, Paul MA. Trimodality therapy for superior sulcus tumors: evolution and evaluation of treatment protocol. EJSO 2013; 39: 197-203. 